\title{
METHOD VALIDATION FOR DETERMINATION OF ORGANOCHLORINE PESTICIDE RESIDUES IN FOOD AND FEED
}

Brankica Kartalovići ${ }^{*}$, Željko Mihaljev, Nadežda Prica, Sandra Jakšić, Milica Živkov Baloš, Miroslav Ćirković Scientific Veterinary Institute „Novi Sad“, Novi Sad, Serbia

\begin{abstract}
Validation of analytical methods ensures the reliability and accuracy of analytical results. To get a reliable result we performed a validation of the method taking into account all factors that may affect of the result. In this paper we optimized QuEChERS method for food and feed sample preparation as well as instrumental method using gas chromatography with mass spectrometry (GC-MS), and we obtained a method for successful determination of pesticides with calibration through the matrix. In this way, applying calibration through matrix, we satisfied the requirements for precision and reproducibility of the method being less than $20 \%$, the accuracy rate in the range of $70-130 \%$ and method linearity throughout the range of interest.
\end{abstract}

Keywords: validation, matrix, GC-MS, QuEChERS

*brankica.kartalovic@gmail.com 


\title{
VALIDACIJA METODE ZA UTVRĐIVANJE REZIDUA ORGANOHLORNIH PESTICIDA U NAMIRNICAMA I HRANI ZA ŽIVOTINJE
}

\author{
Brankica Kartalović, Željko Mihaljev, Nadežda Prica, Sandra Jakšić, \\ Milica Živkov- Baloš, Miroslav Ćirković \\ Naučni institut za veterinarstvo "Novi Sad", Novi Sad
}

\section{Kratak sadržaj}

Validacijom analitičkih metoda se obezbeđuje pouzdanost i tačnost analitičkih rezultata. Da bismo dobili pouzdane rezultate prilikom validacije metode smo uzeli u obzir sve faktore koji mogu uticati na rezultate ispitivanja. U ovom radu pokazana je optimizacija metode za pripremu uzoraka hrane i hrane za životinje QuECHERs metodom pripreme kao i optimizacija instrumentalne metode gasne hromatografije (GCMS) za određivanje pesticida u različitim matrixima. Na ovaj način. kalibracijom kroz matrix, dobili smo rezultate preciznosti i ponovljivosti koji su manji od 20\%, tačnost se kretala u opsegu od $70-130 \%$ a metoda je bila linearna u celom opsegu od interesa.

Ključne reči: validacija, matrix, GCMS, QuECHERS

\section{INTRODUCTION}

Pesticides are chemical compounds, which are used for the removal, suppression and destruction of plant and other pests. Unlike the majority of pollutants that are introduced into the environment without specific targets, pesticides are introduced with the intention to help the man, to increase nutrition and to protect the environment in the "fight" against harmful microorganisms and numerous pests (Stajkovac. 2009). Analysis of organochlorine pesticides (OCP) in food and feed samples comprises application of the number of methods in order to prepare samples for analysis and determination, depending on the type of the samples. Anastassiades et.al (2003) were the first who developed Quick, Easy, Cheap, Effective, Rugged and Safe approach (QuEChERS) method for sample preparation, which gave fast, efficient and reliable result of preparation in optimal time. To eliminate the influence of matrix, calibration through matrix that does not contain pesticide was performed as well. Identification of pesticide residues is complex procedure, and moni- 
toring of low concentrations requires the use of highly sensitive instrumental analytical techniques,gas chromatography with mass spectrometry(GC-MS) or high performance liquid chromatography (HPLC).GC-MS predominates in the testing's due to its greater selectivity and sensitivity as compared to other analytical methods. The aim of this study was to validate the method for determination of organochlorine pesticides set down by regulations in Serbia ("Official Gazette"RS. 29/2014) in food and feed by GC-MS technique after sample preparation applying QuEChERS method.

\section{MATERIALS AND METHOD}

Solvents and chemicals that were used in the validation process were HPLC gradient grade (Merck. Germany). Calibrant solutions were prepared using the pesticides mix of 20 pesticides (organochlorine pesticides mixture, manufacturer Ultra Scientific. lot CL-1069).Spiked samples were used to the purpose of internal control of the following parameters: recovery, precision, limit of quantification (LOQ) and limit of detection (LOD). Pesticides mix that contains 19 pesticides (Chlorinated Pesticides-herbicides, AccuStandard. Inc. lot: 213091108) was used for spike preparation. In order to eliminate the influence of the matrix, calibration through matrix blank sample was performed as well (SANCO, 2014).

\begin{tabular}{|c|c|c|c|c|}
\hline Matrix & $\begin{array}{c}\text { Representa- } \\
\text { tive sample } \\
\text { matrix }\end{array}$ & $\begin{array}{c}\text { Number of } \\
\text { samples }\end{array}$ & $\begin{array}{c}\text { Sample amo- } \\
\text { unt }(\mathrm{g})\end{array}$ & $\begin{array}{c}\text { Expected } \\
\text { concentrati- } \\
\text { on in matrix } \\
(\mathrm{mg} / \mathrm{kg})\end{array}$ \\
\hline $\begin{array}{c}\text { Meat and meat } \\
\text { products }\end{array}$ & Meat & 10 & 3 & 0.005 \\
\hline $\begin{array}{c}\text { Milk and milk } \\
\text { products }\end{array}$ & Whey powder & 10 & 3 & 0.005 \\
\hline $\begin{array}{c}\text { Eggs and egg } \\
\text { products }\end{array}$ & Melange & 10 & 3 & 0.005 \\
\hline Feedstuff & Fishmeal & 10 & 3 & 0.005 \\
\hline
\end{tabular}

Table 1 The matrix and the amount of working solution for LOQ and LOD determination. 
Table 2 Representative matrix and the amount of working solution for spike with the aim of determining the precision and reproducibility

\begin{tabular}{|c|c|c|c|c|}
\hline Matrix & $\begin{array}{c}\text { Representa- } \\
\text { tive sample } \\
\text { matrix }\end{array}$ & $\begin{array}{c}\text { Number of } \\
\text { samples }\end{array}$ & $\begin{array}{c}\text { Sample amo- } \\
\text { unt }(\mathrm{g})\end{array}$ & $\begin{array}{c}\text { Expected } \\
\text { concentrati- } \\
\text { on in matrix } \\
\text { (mg/kg) }\end{array}$ \\
\hline $\begin{array}{c}\text { Meat and meat } \\
\text { products }\end{array}$ & Meat & 20 & 3 & 0.05 \\
\hline $\begin{array}{c}\text { Milk and milk } \\
\text { products }\end{array}$ & Whey powder & 20 & 3 & 0.05 \\
\hline $\begin{array}{c}\text { Eggs and egg } \\
\text { products }\end{array}$ & Melange & 20 & 3 & 0.05 \\
\hline Feedstuff & Fishmeal & 20 & 3 & 0.05 \\
\hline
\end{tabular}

This method of sample preparation is based on the extraction with acetonitrile in the presence of anhydrous magnesium sulfate $(\mathrm{MgSO} 4)$ and anhydrous sodium acetate $(\mathrm{CH} 3 \mathrm{COONa})$. Sample $(3 \mathrm{~g})$ is measured and transferred into centrifuge tube, $3 \mathrm{~mL}$ of water is added and $3 \mathrm{~mL}$ of acetonitrile. After intensive stirring on a vortex, $3 \mathrm{~g}$ of anhydrous magnesium sulphate and $1 \mathrm{~g}$ of anhydrous sodium acetate were added. Exothermic reaction occurred within 1 min after the intense stirring on vortex. The sample was then centrifuged until $5 \mathrm{~min}$ at $3000 \mathrm{rpm} .1 \mathrm{~mL}$ of upper acetonitrile extract is transferred into the 5 $\mathrm{ml}$ tube, which contained $150 \mathrm{mg}$ of anhydrous magnesium sulphate, $100 \mathrm{mg}$ of Primary and Secondary Amine (PSA) and $50 \mathrm{mg}$ of C18 (Anastassiades et al. 2003). The tube content was centrifuged for $5 \mathrm{~min}$ at $3000 \mathrm{rpm}$. After centrifuging, purified and clear extract is obtained. Then, $0.5 \mathrm{~mL}$ of the extract is evaporated in nitrogen and reconstituted with hexane. A sample prepared in this way is ready for the analysis on GC-MS (Agilent 7890B/5977A).

Organochlorine pesticides are separated on DB-5MS column $(30 \mathrm{~m} \cdot 0.25$ $\mu \mathrm{m} \cdot 0.25 \mathrm{~mm}$ ). Sample volume of $4 \mu \mathrm{L}$ (splitless mode) was injected at the constant pressure of $11.36 \mathrm{psi}$ and and flowed through the column of the carrier gas at the flow rate $1.2 \mathrm{~mL} / \mathrm{min}$. The list of analyzed OCP as well as retention time, molecule weight, ions important for the analysis of $\mathrm{HCH}$ isomer are shown in Table 3. The target and qualifier abundances were determined by injecting the mixture of pesticide standards under the same chromatographic conditions using full scan with the mass/charge ratio ranging from 60 to $500 \mathrm{~m} / \mathrm{z}$. Standards were prepared in blank matrix extracts to counteract the matrix effect 
(SANCO. 2014). With the aim of obtaining more reliable results, further pesticide quantification was performed in SIM mode. Pesticide quantification was performed according to mass spectra and characteristic ions defined in SIM mode (Table 4), as well as the retention time of exit components, pesticides (Selvi et al. 2012). The processing of the obtained data was performed applying Mass Hunter Software. The analysis of the method performance is performed in a calibration range from 0.005 to $0.1 \mathrm{mg} / \mathrm{kg}$.

Table 3 Retention time (RT), molecule mass (MW), primary (target) ion (T) and secondary and tertiary ion (Qualifier Ions, Q1, Q2).

\begin{tabular}{|c|c|c|c|c|c|}
\hline Pesticide & RT(min) & MW & T & Q1 & Q2 \\
\hline$\alpha$ HCH & 11.28 & 290.8 & 181 & 181 & 219 \\
\hline$\beta$ HCH & 12.47 & 290.8 & 183 & 181 & 183 \\
\hline$\gamma$ HCH (lindane) & 12.57 & 290.8 & 181 & 183 & 109 \\
\hline$\delta$ HCH & 13.74 & 290.8 & 109 & 219 & 183 \\
\hline heptachlor & 15.74 & 370 & 272 & 235 & 237 \\
\hline aldrine & 17.40 & 362 & 263 & 220 & 291 \\
\hline heptachlorepoxide & 19.55 & 386 & 353 & 81 & 355 \\
\hline trans-chlordane & 20.88 & 406 & 373 & 375 & - \\
\hline alpha endosulfan & 21.46 & 404 & 195 & 159 & 133 \\
\hline cis chlordane & 21.71 & 406 & 373 & 375 & - \\
\hline pp'DDE & 22.84 & 378 & 79 & 277 & 239 \\
\hline dieldrine & 23.09 & 316 & 246 & 176 & 211 \\
\hline endrin & 23.80 & 378 & 263 & 191 & 226 \\
\hline endosulfan & 24.26 & 404 & 195 & 157 & 159 \\
\hline pp'DDD & 24.90 & 318 & 235 & 165 & 237 \\
\hline endrin aldehyde & 25.065 & 378 & 67 & 345 & - \\
\hline endosulfansulfate & 25.97 & 420 & 272 & 274 & 387 \\
\hline pp'DDT & 26.26 & 352 & 235 & 165 & 200 \\
\hline methoxychlor & 26.88 & 344 & 227 & 165 & 184 \\
\hline endrin ketone & 27.46 & 240 & 317 & 67 & - \\
\hline
\end{tabular}


Table 4 SIM program was used for the analysis and confirmation $(\mathrm{m} / \mathrm{z}$. total dwell time)

\begin{tabular}{|c|c|c|c|c|}
\hline Group & $\begin{array}{c}\text { Time } \\
(\mathrm{min})\end{array}$ & Pesticide & $\mathrm{m} / \mathrm{z}$ & Total dwell time \\
\hline 1 & 10.78 & $\begin{array}{c}\alpha \mathrm{HCH}, \beta \mathrm{HCH}, \\
\gamma \mathrm{HCH}, \delta \mathrm{HCH}\end{array}$ & $181,219,109$ & 150 \\
\hline 2 & 14.98 & heptachlor & $100,237,272$ & 150 \\
\hline 3 & 16.66 & aldrine & $66,263,293$ & 150 \\
\hline 4 & 18.84 & $\begin{array}{c}\text { heptachlor } \\
\text { epoxide }\end{array}$ & $81,353,237,263$ & 200 \\
\hline 5 & 20.37 & $\begin{array}{c}\text { Cis, trans-chlordane, } \\
\text { endosulfan I }\end{array}$ & $\begin{array}{c}373,237,272, \\
195,237,170\end{array}$ & 300 \\
\hline 6 & 22.38 & $\begin{array}{c}\text { Dieldrine. } \\
\text { pp'DDE }\end{array}$ & $\begin{array}{c}79,263,246, \\
176,318\end{array}$ & 250 \\
\hline 7 & 23.45 & $\begin{array}{c}\text { Endrin, En- } \\
\text { dosulfan II }\end{array}$ & $\begin{array}{c}81,67,263,245, \\
195,237,243\end{array}$ & 350 \\
\hline 8 & 24.62 & $\begin{array}{c}\text { pp'DDD. en- } \\
\text { drin aldehyde }\end{array}$ & $\begin{array}{c}235,165, \\
67,173,250\end{array}$ & 250 \\
\hline 9 & 25.29 & $\begin{array}{c}\text { pp'DDT. endo- } \\
\text { sulfansulfate }\end{array}$ & $\begin{array}{c}165,235,237, \\
275,387,422\end{array}$ & 300 \\
\hline 10 & 26.56 & $\begin{array}{c}\text { methoxychlor } \\
227,152\end{array}$ & 100 \\
\hline 11 & 27.14 & $\begin{array}{c}\text { endrin ketone } \\
\text { end, 317, 345 }\end{array}$ & 150 \\
\hline
\end{tabular}

\section{RESULTS AND DISCUSSION}

Based on tests conducted on five representative matrices and implemented to the internal controls, we obtained the results shown in Tables 5 and 6 . Validation plan included determination of linearity, precision, reproducibility, accuracy and LOQ and LOD.

Linearity that was determined by setting a calibration curve was tested by regression analysis to establish the mathematical relationship between concentration and results in a set range of resultant values. 
The precision of the method represents an agreement between values obtained in a series of repeated measurements of the same homogenous sample under the same determination conditions by at least 5 repeated measurements of the representative spiked matrix.

The reproducibility of the method represents matching results obtained by successive measurements of the same samples, but under many different conditions, determination is accomplished by analyzing at least 5 spiked samples (representative matrix).

The accuracy represents the mean value of the obtained results and actual or accepted value of the results. It is expressed as the yield (recovery), calculated on the spiked sample in relation to the expected theoretical value of the results.

LOQ is the lowest concentration that can be determined with reasonable accuracy. It is calculated as the sum of the mean values of 10 repetitions and 3 standard deviations.

LOD , granica detekcije, je najniza koncentracija analita koja može biti dokazana ali ne i određena. Izračunava se kao zbir srednje vrednosti od deset ponavljanja na matrix spajku , koji odgovara prvoj tački kalibracije, i 10 standardnih devijacija.

Table 5 The average values of accuracy, reproducibility, accuracy, linearity, LOQ and LOD for all matrices

\begin{tabular}{|c|c|c|c|c|c|c|}
\hline Pesticides & $\begin{array}{c}\text { Precisi- } \\
\text { on (\%) }\end{array}$ & $\begin{array}{c}\text { Reproduci- } \\
\text { bility }(\%)\end{array}$ & $\begin{array}{c}\text { Accuracy } \\
(\%)\end{array}$ & $\begin{array}{c}\text { Linearity } \\
\left(\mathrm{R}^{2}\right)\end{array}$ & $\begin{array}{c}\text { LOQ } \\
(\mathrm{mg} / \mathrm{kg})\end{array}$ & $\begin{array}{c}\text { LOD } \\
(\mathrm{log} / \mathrm{kg})\end{array}$ \\
\hline$\alpha \mathrm{HCH}$ & 4.35 & 5.22 & 96.07 & 0.9990 & 0.0047 & 0.0014 \\
\hline$\beta \mathrm{HCH}$ & 17.91 & 8.88 & 99.14 & 0.9918 & 0.0019 & 0.0006 \\
\hline$\gamma \mathrm{HCH}$ (lindane) & 8.98 & 8.32 & 99.64 & 0.9980 & 0.001 & 0.0003 \\
\hline$\delta \mathrm{HCH}$ & 0.8 & 18.2 & 100.32 & 0.9993 & 0.0042 & 0.0003 \\
\hline heptachlor & 3.39 & 14.64 & 88.08 & 0.9979 & 0.001 & 0.0003 \\
\hline aldrine & 3.57 & 3.44 & 98.3 & 0.9904 & 0.0046 & 0.0014 \\
\hline heptachlorepoxide & 3.52 & 3.36 & 94.37 & 0.9973 & 0.0016 & 0.0005 \\
\hline trans-chlordane & 4.37 & 8.22 & 90.16 & 0.9981 & 0.0012 & 0.0004 \\
\hline alpha endosulfan & 9.32 & 8.7 & 87.27 & 0.9977 & 0.0028 & 0.0009 \\
\hline cis chlordane & 4.3 & 8.22 & 91.55 & 0.9993 & 0.0039 & 0.0012 \\
\hline
\end{tabular}




\begin{tabular}{|c|c|c|c|c|c|c|}
\hline Pesticides & $\begin{array}{c}\text { Precisi- } \\
\text { on (\%) }\end{array}$ & $\begin{array}{c}\text { Reproduci- } \\
\text { bility (\%) }\end{array}$ & $\begin{array}{c}\text { Accuracy } \\
(\%)\end{array}$ & $\begin{array}{c}\text { Linearity } \\
\left(\mathrm{R}^{2}\right)\end{array}$ & $\begin{array}{c}\text { LOQ } \\
(\mathrm{mg} / \mathrm{kg})\end{array}$ & $\begin{array}{c}\text { LOD } \\
(\mathrm{log} / \mathrm{kg})\end{array}$ \\
\hline pp'DDE & 3.14 & 3.87 & 96.87 & 0.9965 & 0.0048 & 0.0014 \\
\hline dieldrine & 3.52 & 3.36 & 94.37 & 0.9924 & 0.005 & 0.0015 \\
\hline endrin & 8.51 & 16.21 & 83.41 & 0.9942 & 0.0031 & 0.0009 \\
\hline endosulfan & 7.77 & 10.25 & 91.24 & 0.9986 & 0.0049 & 0.0015 \\
\hline pp'DDD & 5.69 & 14.29 & 81.57 & 0.9991 & 0.0039 & 0.0012 \\
\hline endrin aldehyde & 5.57 & 10.46 & 85.62 & 0.9979 & 0.0044 & 0.0013 \\
\hline endosulfansulfate & 13.7 & 15.3 & 116.3 & 0.9990 & 0.0046 & 0.0014 \\
\hline pp'DDT & 3.52 & 3.36 & 94.37 & 0.9918 & 0.0048 & 0.0014 \\
\hline methoxychlor & 7.67 & 1.84 & 106.09 & 0.9980 & 0.0021 & 0.0006 \\
\hline min & $\mathbf{0 . 8}$ & $\mathbf{1 . 8 4}$ & $\mathbf{8 1 . 5 7}$ & $\mathbf{0 . 9 9 0 4}$ & $\mathbf{0 . 0 0 1}$ & $\mathbf{0 . 0 0 0 3}$ \\
\hline max & $\mathbf{1 7 . 9 1}$ & $\mathbf{1 8 . 2}$ & $\mathbf{1 1 6 . 3}$ & $\mathbf{0 . 9 9 9 3}$ & $\mathbf{0 . 0 0 5}$ & $\mathbf{0 . 0 0 1 5}$ \\
\hline
\end{tabular}

Table 6 Data obtained from internal quality control for the different matrices (mean values Xsr, STD, RSD, Bias Recovery, N number of measurements for each pesticide)

\begin{tabular}{|c|c|c|c|c|c|c|}
\hline Matrix & $\mathrm{N}$ & $\begin{array}{c}\text { Xsr }(\mathrm{mg} / \\
\mathrm{kg})\end{array}$ & STD & RSD (\%) & Bias (\%) & $\begin{array}{c}\text { Recovery } \\
(\%)\end{array}$ \\
\hline Fishmeal & 20 & 0.053 & 0.010 & 19.438 & 7.095 & 106.330 \\
\hline $\begin{array}{c}\text { Whey } \\
\text { powder }\end{array}$ & 20 & 0.055 & 0.005 & 9.818 & 9.697 & 109.183 \\
\hline Meat & 20 & 0.048 & 0.010 & 18.807 & 11.176 & 96.607 \\
\hline Melange & 20 & 0.047 & 0.008 & 16.052 & 7.814 & 93.916 \\
\hline Honey & 20 & 0.052 & 0.005 & 10.523 & 3.960 & 103.960 \\
\hline Xsr & $\mathbf{2 0}$ & $\mathbf{0 . 0 5 1}$ & $\mathbf{0 . 0 0 7 6}$ & $\mathbf{1 4 . 9 2 7}$ & $\mathbf{7 . 9 4 8}$ & $\mathbf{1 0 1 . 9 9 9}$ \\
\hline
\end{tabular}

According to study of Maštovská et al. (2005), as compared to matrixmatched standardization, the analyte protectant approach offers a more convenient solution to the problems associated with calibration in routine GC/ MS analysis of pesticide residues and possibly other susceptible analyte types in diverse samples. In a study on Alternative calibration techniques for coun- 
teracting the matrix effects in GC-MS-SPE pesticide residue analysis, Rimayi (2015) shows descriptive and inferential statistics proving that the matrixmatched internal standard calibration was the best approach for samples of varying matrix composition since it produced the most precise average mean recovery of $87 \%$ across all matrices tested. We demonstrated the same in our testing. Kartalovic et al. (2015) suggested application of gas chromatography with mass detector for the determination of pesticide traces, as it provides us with a confirmation of result reliability by comparing the obtained spectrum with that from the library. GCMS analysis offers good precision and recovery rate for determination of pesticides in hake fillets when applying matrix calibration (Kartalovic et al., 2015b).

\section{CONCLUSION}

Based on the conducted research and appropriate preparation, calibration and verification of the representative matrix we can conclude that the method for determination of pesticide residues in food and feed meets the eligibility criteria required by SANCO (2014). The method is linear in the range of 0.005 to $0.1 \mathrm{mg} / \mathrm{kg}$. The linearity factor $\left(\mathrm{R}^{2}\right)$ is higher than 0.99 . The precision and reproducibility rate for pesticide determination is a greater than $20 \%$. The accuracy of the method is in the range $70-130 \%$. The method can be successfully used for the determination of pesticide residues in food and feed.

\section{ACKNOWLEDGMENT}

The presented work is the part of the research done in the framework of the project TR31084 granted by the Serbian Ministry of Education, Science and Technological Development.

\section{LITERATURE}

1. Anastassiades M. Lehotay S.: Fast and Easy Multiresidue Method Employing Acetonitrile Extraction/Partitioning and "Dispersive Solid-Phase extraction" for the Determination of Pesticide Residues in Produce. Journal of AOAC International. 86(2). 2003.

2. Cornelius Rimayi .DavidOdusanya Fanyana. Mtunzi.Shepherd Tsoka: Alternative calibration techniques for counteracting the matrix effects in GC-MS-SPE pesticide residue analysis - A statistical approach. Chemosphere Volume 118. Pages 35-43. 2015. 
3. Jugoslav Stajkovac. Branka Amidžić. Jelena Biočanin: Pesticidi i izvori zagađenja u životnoj sredini i značaj remedijacije u sanaciji kontaminacije. 1st International Conference 'Ecological safety in post-modern environment'. Banja Luka.RS. BiH. 26-27. Juny 2009.

4. Kateřina Maštovská . Steven J. Lehotay . Michelangelo Anastassiades: Combination of Analyte Protectants To Overcome Matrix Effects in Routine GC Analysis of Pesticide Residues in Food Matrixes. Anal. Chem. 77 (24). pp 8129-8137. 2005.

5. Kartalović B. Babić J. Prica N. Živkov-Baloš M. Jakšić S. Mihaljev Ž. Ćirković M.: The presence of Lindane in different types of honey in the Pannonian region. Bulgarian Journal of Agricultural Science. ISSN 1310-0351. 208-212. 2015

6. Kartalović B.. Živkov-Baloš M.. Prica N.. Babić J.. Jovanić S.. Petrović J.. Ćirković M.: Presence of organochlorine pesticides in hake fillets. VII International Conference 'Water \& Fish'. Belgrade-Zemun. Serbia June. 1012. 2015. editors in chief Vesna Poleksić and Zoran Marković. Conference Proceedings. 293-297. Belgrade. University. Faculty of Agriculture. 2015b

7. Pravilnik o maksimalno dozvoljenim količinama ostataka sredstava za zaštitu bilja u hrani i hrani za životinje i o hrani i hrani za životinje za koju se utvrđuju maksimalno dozvoljene količine ostataka sredstava za zaštitu bilja. Beograd. JP „Službeni glasnik“Republike Srbije. 29/2014.

8. SANCO. Guidance document on analytical quality control and validation procedures for pesticide residues analysis in food and feed. Supersedes SANCO/12495/2011 Implemented by 01/01/2014.

9. Selvi C. Paramasivam M. Rajathi D. S. Chandrasekaran S.: Multiresidue analysis of organochlorine pesticides in milk. egg and meat by GC-ECD and confirmation by GC-MS. Bull Environ Contam Toxicol. 89: 1051-1056. 2012. 